\title{
Awkward partners? The British Labour party and European integration in the 1970 s
}

Book or Report Section

Accepted Version

Broad, M. (2015) Awkward partners? The British Labour party and European integration in the 1970s. In: Thiemeyer, G. and Raflik, J. (eds.) European political parties and the first direct elections to the European Parliament. Nomos, Baden-Baden, Germany, pp. 119-141. ISBN 9783848719921 Available at http://centaur.reading.ac.uk/40163/

It is advisable to refer to the publisher's version if you intend to cite from the work. See Guidance on citing.

Publisher: Nomos

All outputs in CentAUR are protected by Intellectual Property Rights law, including copyright law. Copyright and IPR is retained by the creators or other copyright holders. Terms and conditions for use of this material are defined in 
the End User Agreement.

www.reading.ac.uk/centaur

\section{CentAUR}

Central Archive at the University of Reading

Reading's research outputs online 


\title{
Awkward partners? The British Labour party and European integration in the 1970s
}

\author{
Book chapter (accepted version) \\ Published in Guido Thiemeyer and Jenny Raflik (eds.), European Political \\ Parties and the First Direct Elections to the European Parliament (Nomos: \\ Baden-Baden, 2015), pp. 119-141
}

In late February 1970, members of the British House of Commons gathered to debate the White Paper on Britain's potential membership of the European Community (EC). Opening the session for the Labour government, the Foreign Secretary, Michael Stewart, explained how the party's approach to the EC »has been steadily based since $1967 \ll . »$ We have made our application«, Stewart continued, $\gg$ it stands, we press it, we desire that negotiations should be opened. And we are anxious that they should succeed ${ }^{1}$. While there were still important questions to answer regarding British accession - not least the economic arguments over which the White Paper was in part designed to address - Stewart did not stop at insisting that London was once again prepared to enter into negotiations with Brussels. It also, he made clear, firmly believed that the Six now wanted to see Britain join. After nearly a decade of trying, it seemed that British accession was finally at hand.

There was a good deal to suggest that on the third time of asking Britain might well end up in an enlarged Community as Stewart hoped. For a start, Charles de Gaulle's departure from the Élysée earlier in April 1969 appeared to mark a new mood in the EC. And by the time of the Hague Summit just eight months later the Community had itself made huge advances in its operation ${ }^{2}$. Not only had the Six agreed to the completion of the EC's transnational period and

\footnotetext{
${ }^{1}$ Hansard, House of Commons Debates, 24 February 1970, vol. 796, col. 997.

${ }^{2}$ On the Hague Summit see in particular the special edition of Journal of European Integration History 9 (2003).
} 
resolved outstanding disagreements over Community financing. They had also taken a decisive step forward in deepening integration to extend the Community's competences into a number of new areas, including economic and monetary union (EMU). Having sorted out two of the most pressing questions concerning its internal workings, Brussels was therefore in a position to turn its attention once more to the third and altogether more controversial of its aims: enlargement.

The Labour leadership was likewise optimistic that the party would once again swing behind the government and support the bid to join the Community. After all, and thanks mostly to cajoling on the part of leader and then prime minister Harold Wilson, Labour ministers had endorsed the principle of British membership back in $1967^{3}$. The movement more widely, it is true, had divided on the question. But few in the Labour cabinet had found themselves able to disagree that the political arguments in favour of Britain's accession were highly attractive. In the party's October conference of that same year moreover, and in the three subsequent annual meetings up until 1970, Labour had continued to support membership dependent on certain safeguards for Britain and the Commonwealth ${ }^{4}$. Wilson's strategic goal thereafter remained securing membership of the $\mathrm{Six}^{5}$. As tentative negotiations between Britain and the Six opened in the spring of 1970, it thus appeared likely that he would not only achieve his aim but would carry large swathes of the Labour movement with him.

Aware as Wilson and Stewart both no doubt still were of the difficulties in keeping Labour united over 〉Europe $<$, neither man could scarcely have predicted the scale of the problems that they would soon encounter. A measure of just how toxic the debate would become was already clear when, within a year of returning to opposition in June 1970, the party rejected the terms of Britain's accession to the Community. Due in no small part to the ascendency of the Labour left, by March 1972 the ruling National Executive Committee (NEC) pledged both to

\footnotetext{
${ }^{3}$ Helen PARR, Britain's policy towards the European Community. Harold Wilson and Britain's world role, 1964-1967, Abingdon 2006, p. 146-147.

${ }^{4}$ Labour Party, Labour Party Annual Report, London 1967, p. 329-332. The conditions were: safeguards for the Commonwealth, protection for the other countries of the European Free Trade Area, freedom to plan foreign, economic and social policy, and safeguards for British agriculture.

${ }^{5}$ Melissa PINE, Harold Wilson and Europe. Pursuing Britain's membership of the European Communities, London 2007, p. 1.
} 
renegotiate the so-called \Tory terms` agreed by Edward Heath and, if successful, hold a referendum on continued membership. It was only Wilson's threat of resignation in October the following year that prevented the conference going even further and supporting withdrawal altogether ${ }^{6}$. Considering that Labour regarded Britain's membership as effectively in suspense, the Parliamentary Labour Party (PLP) did however agree in the meantime to boycott its seats in the European Parliament (EP). Within a matter of three years, it appeared that Labour had abruptly shifted its entire approach to British entry.

Nor could they have foreseen the hostility that would continue to dominate the party's approach to membership after regaining power in February 1974. Much of Labour's attention centred initially on the 1975 referendum. But even after this, party sentiment not only remained antagonistic but seemed to turn increasingly anti-federalist. The NEC for instance objected to British inclusion in EMU and called for reforms to a whole raft of existing Community policies. If Labour was hostile, however, nowhere was it perhaps more obvious than over its response to cooperation with socialist groups within the Community. According to earlier accounts at least, Labour found membership of the Confederation of the Socialist Parties of the EC an »unacceptable constraint on its autonomy« and refused to join it as anything other than an observer ${ }^{7}$. Part of this hostility, so the story goes, also fed into doubts over association with the Socialist Group in the $\mathrm{EP}$, an issue once again after Labour had reneged on its earlier boycott in light of the referendum result ${ }^{8}$. Soon enough the party was criticising direct elections and, having accepted them as inevitable, refused to have its candidates stand on a joint platform with the Confederation in the first direct elections of June 1979. To make matters worse, the result was a disaster for Labour, the party barely winning a third of the seventy-eight seats available. Britain may well have secured entry as

\footnotetext{
${ }^{6}$ Harold WiLSON, Final Term: The Labour Government 1974-76, London 1979, p. 51.

${ }^{7}$ Simon HIX and Christopher LORD, A model transnational party? The Party of European Socialists, in: David S. BELL and Christopher LORD (eds.) Transnational parties in the European Union, Ashgate 1998, p. 89. See also Jens Henrik HAAHR, Looking to Europe. The EC policies of the British Labour Party and the Danish Social Democrats, Aarhus 1993, p. 80-81.

${ }^{8}$ Roger BROAD, Labour's European dilemmas. From Bevin to Blair, Basingstoke 2001, p. 124.
} 
Stewart had predicted nine years earlier, but in the process Labour had seemingly become electorally irrelevant at home and increasingly isolated abroad.

What follows in this chapter is not an attempt fundamentally to reinterpret this picture. There is after all no escaping that in the 1970s Labour split over the question of British membership of the EC. With an eye to events beyond the national setting and by paying particular attention to the interaction between Labour and its socialist counterparts, however, what this chapter will do is suggest two main reasons that the story presented above was a little more complex. For while elements of the party certainly did reject forms of cooperation in the form of the Confederation and the Socialist Group in the EP, informal transnational relations outside the Community framework remained a mainstay in the leadership's approach to the integration process throughout the 1970s. Labour's more general criticism of European integration, to put it another way, did not negate the importance of cross-border political contact for the party elite. A second reason to be slightly more sceptical of this narrative it will argue is that such scepticism within the party did not prevent the Labour leadership from doing its utmost to ensure full participation within both the Confederation and the EP Socialist Group. Traditional descriptions of the party being wholly against such cooperation prior to direct elections in 1979, it will thus propose, are somewhat simplistic. As divided as the party doubtless was, then, its links with other socialist groups do perhaps need to be given greater weight in order to understand a little more fully this most fundamental period in Labour's recent history.

\section{Labour, >Europe $<$ and the beginning of party cooperation}

Conventional wisdom on Labour and European integration has the party following a largely negative line after the Second World War. The point often made, with clear justification, is that at the heart of Labour thinking after 1945 were not European affairs but rather global ones ${ }^{9}$. Under the administration of Clement Attlee, Labour was certainly far more concerned about maintaining closer links

\footnotetext{
${ }^{9}$ BROAD, Labour's European dilemmas (as in n. 8), p. 4-17; Rhiannon VICKERS, The evolution of Labour's foreign policy 1900-51, Manchester 2004, p. 159-187.
} 
with the white Commonwealth, and to a lesser extent with the United States and Asia, than developing them with continental European states ${ }^{10}$. In office there were of course clear exceptions to this rule, including with the creation of the Organisation for European Economic Cooperation (OEEC) in April 1948. Yet those organisations in which Britain was involved were all notable for their distinctly intergovernmental frameworks. In many cases Labour ministers negotiated opt-outs and exceptions that retained Whitehall's decision-making capacity. By contrast, supranationalism was something viewed as dangerous, an infringement on both national sovereignty and the right of the party to plan its own economic and political course for Britain. It was this attitude that coloured Labour's initial response to the European integration process. In its official response to the Schuman Plan for instance the party declared unambiguously how »no Socialist Party with the prospect of forming a government could accept a system by which important fields of national policy were surrendered to a supranational European representative authority « ${ }^{11}$. And this attitude clearly fed through into its attitude towards European cooperation well into the 1960s. Indeed, as recent research has shown, it was in fact not until around 1966 that Labour `turned towards EC membership, and only then as a pragmatic response to Britain's shifting world role ${ }^{12}$.

Less often discussed in the literature but doubtless still very significant is the idea that Labour did not react to all of these developments alone; the party's continuing evaluation of the integration process was in fact often carried out in tandem with other socialist groups in Western Europe. To those in Labour perhaps suspicious of >continental socialists, contact of this type was not always welcome. As Denis Healey never tired of arguing, informal relations between Labour and its Scandinavian counterparts often held greater weight for the party than relations with other socialist groups ${ }^{13}$. And it is perhaps no accident that it

\footnotetext{
${ }^{10}$ Labour Party, Labour Party Annual Report, London 1945, p. 115.

${ }^{11}$ Labour Party, European Unity. A Statement by the National Executive Committee of the British Labour Party, London 1950, p. 8.

${ }^{12}$ PARR, Britain's policy (as in n. 3), p. 185-190.

${ }^{13}$ Denis Healey, The International Socialist Conference 1946-50, in: International Affairs 25 (1950), p. 364; Denis Healey, The Time Of My Life, London 1989, p. 95.
} 
was Labour and its sister groups across the North Sea that had earlier led the charge against the newly inaugurated Socialist International enforcing binding decisions on national parties ${ }^{14}$. At the same time, discussions on topics such as the Schuman Plan were a constant item on the International's agenda after 1951 - and Healey, as Labour's then international secretary, was in fact a central player in such dialogue ${ }^{15}$. Nor did Labour's earlier reluctance prevent it from participating in the Contact Committee of the Socialist International, established by socialist parties in the aftermath of the November 1958 collapse of the Free Trade Area (FTA) plan $^{16}$. Very quickly, it seemed, Labour had learnt the value of transnational party cooperation in the overall development of British European policy.

Importantly, this type of informal cooperation would continue well beyond the FTA issue. It did so in three main ways. First, there was the Contact Committee itself. Its inaugural meeting in January 1959 saw Labour and other groups pool ideas for longer-term alternatives to the FTA. All were convinced that a smaller trade area of the non-Six would be both damaging economically and have implications for the defence of Western Europe within an increasingly tense cold war environment. Hence, Labour agreed - beyond what was then official party policy - to work with its socialist counterparts towards a »socialist formula« to foster closer links between the Community and what became the European Free Trade Association (EFTA) ${ }^{17}$. Thereafter, Labour made habitual use of the Contact Committee to garner information about developments within the Community from

\footnotetext{
${ }^{14}$ Labour History Archives and Study Centre, Manchester [henceforth LHA], Denis Healey International Department papers, Box 3, Denis Healey to Hugh Dalton, 12 February 1946 and Dalton to Healey, 18 February 1946. On the creation of the Socialist International see Julius BRAUNTHAL, History of the International. World Socialism 1943-1968. London 1980.

${ }^{15}$ See for instance Arbejdermuseet \& Arbejderbevægelsens Bibliotek og Arkiv, Copenhagen [henceforth ABA], Danish SD archive [henceforth SDA], Box 342, Report of the Conference of the Socialist International in Brussels 14-16 December 1951, circular no. 15/52, 31 January 1952.

${ }^{16}$ The FTA was a British proposal to confront the creation of the EC by creating an industrial free trade zone of the seventeen OEEC states. On reasons for Labour's decision to participate in the Contact Committee, see LHA, NEC Minutes 17 December 1958, minutes of joint meeting of finance and economic policy and European cooperation sub-committees, 25 November 1958. On the collapse of the FTA, see among others James ElLISON, Threatening Europe. Britain and the Creation of the European Community 1955-58, Basingstoke 2000, p. 189-220.

${ }^{17}$ International Institute for Social History, Amsterdam [henceforth IISH], Socialist International archive, Box 585, Carthy to Krag, 3 March 1960.
} 
the socialist parties of the Six or to liaise with other socialist groups from EFTA ${ }^{18}$. Nearly a decade of collaboration later and the Contact Committee was still a useful platform. Labour even used one such meeting of the Committee at the end of September 1967 to coerce the EC socialist parties to pressure their respective governments into launching negotiations for British membership despite de Gaulle's >velvet veto $<$ four months earlier ${ }^{19}$.

A second but no less important structure was the framework of the Socialist International. In May 1966, Labour's deputy leader George Brown used a meeting of the bureau of the Socialist International to seek support for a future application by Labour to the Community, although at this stage he stopped short of confirming whether Labour actually would join ${ }^{20}$. Over three years later, Wilson likewise used the International's congress in Eastbourne as a vehicle to build consensus around a new British application following the election of Georges Pompidou $^{21}$.

But it was a third arena - informal leadership meetings outside of the Socialist International and based on the informal nature of the Contact Committee - that soon proved the most useful network of all. Certainly, Wilson preferred to meet his party counterparts informally, usually with brandy in hand, than through other channels open to $\mathrm{him}^{22}$. No gathering was perhaps more significant than that at Chequers in April 1965, when leaders from the British, Danish, Norwegian, Swedish, Austrian and German parties met to discuss once again expanding links between the EC and the seven members of EFTA. Recent research has suggested that this meeting confirms that Wilson was committed to joining the Community

\footnotetext{
${ }^{18}$ LHA, Labour international department papers, Box 3, Summary Report of Meeting of the Contact Committee of the Socialist International, 2 July 1961.

${ }^{19}$ IISH, Socialist International Archive, Box 591, Notes of meeting of the Contact Committee on Europe, 25 September 1967. The best discussion on the 'velvet veto' remains Uwe KITZINGER, The Second Try. Labour and the EEC, Oxford 1968, p. 179-188.

${ }^{20}$ ABA, Jens Otto Krag papers, Box 144, transcript of speech by Brown to Socialist International, 5 May 1966.

${ }^{21}$ Bodleian Library, University of Oxford [henceforth Bodleian], Harold Wilson papers, MS. Wilson c. 1250, transcript of speech by Wilson to Socialist International, 16 June 1969.

${ }^{22}$ Bodleian, Harold Wilson papers, MS. Wilson c. 1282, note by Harold Wilson, 21 January 1969.
} 
in $1965^{23}$. The relevant sections of the papers of Jens Otto Krag, the leader of the Danish Social Democrats (Socialdemokratiet, SD), indicate in fact that Wilson was more equivocal about British entry ${ }^{24}$. Regardless, and even keeping in mind Wilson's reputation as a cunning politician adept at telling different audiences very different things, it is evidence of a shift in Labour thinking on the EC at the most primitive of stages that few in his own party were privy to. Informal discussions retained their significance thereafter, for other groups as much as Labour. At the end of 1966, in an ad hoc meeting with Labour's George Brown, Krag was even informed that Labour ministers planned to conduct a >probe < of the Six to see whether the conditions existed for another application to the Community. This, as it turned out, was before Labour ministers had even discussed the issue ${ }^{25}$.

\section{Function of party relations}

From the analysis above, we can start to discern a number of the key elements of Labour's relationship with its socialist counterparts on the eve of the 1970s. First, as should already be clear, cross-border party cooperation was essentially an elitedriven process. In its dealings with other groups, Labour was often represented by Gaitskell or later by Wilson as party leader, other senior political figures like George Brown with interests connected to `Europe`, or party workers with foreign policy briefs such as the heads of the overseas and international departments. Labour stalwart and overseas secretary Gwyn Morgan certainly recognised the value of such encounters. As he explained to Haakon Lie of the Norwegian Labour Party (Det Norske Arbeiderpartiet, DNA) in mid-1967, written correspondence was fine but »There will [...] be more major problems; e.g. entry to the $[\mathrm{EC}]$, where a fuller discussion than we can hope to have by

\footnotetext{
${ }^{23}$ Kristian STEINNES, Socialist party networks in northern Europe. Moving towards the EEC applications of 1967, in: Wolfram KaISER, Brigitte LeUCHT and Morten RASMUSSEN (eds.), The History of the European Union. Origins of a trans- and supranational polity 1950-72, Abingdon 2009, p. 96-97.

${ }^{24}$ ABA, Jens Otto Krag papers, Box 76, notes of meeting between Krag and Wilson, 23 April 1965.

${ }^{25}$ National Archives, Kew [henceforth TNA], PREM 13/813, record of meeting between Brown and Krag, 18 October 1966; ABA, Jens Otto Krag papers, Besøg til London, 18 October 1966.
} 
correspondence may be necessary $\aleph^{26}$. At lower levels, by contrast, there were far fewer incidences of engagement with other socialist groups beyond national boundaries. Why this was the case is not immediately obvious from archival material alone. To speculate a little, though, only the Labour leadership or party officials working in foreign policy-related briefs had the financial means and political prestige necessary to meet with senior figures in other groups.

Notwithstanding this point, the very nature of representation in the Socialist International and other more informal meetings meant it was often leading party figures meeting their opposite numbers.

Second, and as is equally axiomatic from the discussion above, such cooperation between Labour and its socialist counterparts in Europe was largely reactionary. The first Contact Committee meeting in 1959 was itself a response to the collapse of the FTA, while the meeting of the Committee in September 1967 came soon after de Gaulle's > velvet veto way, the various speeches delivered to the Socialist International by the likes of Brown and Wilson were symptomatic of changes in the wider political environment in Europe. Brown's May 1966 bureau meeting was of course part of Labour's renewed interest in an application to the Community; Wilson's speech to the congress of the Socialist International in June 1969 came on the back of Pompidou's election and the prospect that Britain might once again seek accession to the Community. In short, Labour did not deploy cooperation for the sake of it; party cooperation was porous and ad hoc, included different actors in different fora at different times, and was responsive to developments at both the national and European levels.

Third, when the Labour leadership did meet other groups, it was principally interested in exchanging information ${ }^{27}$. Meeting with its counterparts gave the Labour elite an insight into the policies pursued by other parties, a chance to gain knowledge about the integration process and the intricacies of membership. The informal nature of the Contact Committee and ad hoc leadership meetings made it

\footnotetext{
${ }^{26}$ LHA, Labour international department papers, LP/ID/NOR/3, Morgan to Lie, 21 August 1967.

${ }^{27}$ See also STEINNES, Socialist party networks (as in n. 23), p. 104.
} 
especially easy for party figures to talk openly and honestly with one another. Importantly, this gave the Labour elite the chance to eschew what at times were deeply bitter internal party squabbles over the issue of British membership and confront the question in the more relaxed atmosphere provided by the transnational setting.

Fourth, this is not to say that transfer of information was the only function of party cooperation; such collaboration was at times equally suited to influencing the policies of other socialist groups. The example of the Contact Committee meeting in September 1967 is an obvious case of this. Labour in this example hoped to build consensus around a British application. By urging socialist parties from the countries of the Six to support the bid, it represented another way both to propagate Labour's goals with regard to the integration process and to pile pressure on de Gaulle. Elsewhere, the ability to influence the policies of other parties proved as much a hindrance to Labour as it did a help. Soon after becoming prime minister for instance, Wilson faced the combined wrath of Scandinavian socialists in a leaders' meeting early in November 1964 over the introduction of a surcharge on British imports. The prevailing belief that the charge undermined political support in EFTA, and the pressure subsequently placed on the Labour leadership by its Scandinavian counterparts in this regard, doubtless helped lead to the later abandonment of the plan ${ }^{28}$.

Of greater relevance to a chapter discussing Labour in the run up to the first direct elections, however, is that all of these elements were as ubiquitous across the 1970s as they were in the late 1950s and 1960s. The archives reveal that in the 1970s there were two distinct phases in the context of Labour's relationship with its socialist counterparts, each of which fall either side of the June 1975 referendum. The next section will thus discuss the moment from when Labour found itself back in opposition in June 1970 until the referendum five years later. The last main section of this chapter will then focus on the period from the referendum through to direct elections in 1979.

\footnotetext{
${ }^{28}$ For instance ABA, Jens Otto Krag papers, Box 144, notes of Salzburg conference of party leaders 9-10 January 1965 , undated.
} 


\section{Towards British membership}

Prior to the 1975 referendum the main function of party cooperation from the perspective of the Labour leadership was to attain, and thereafter secure, British membership of the Community. The results of such activity quickly emerged after Labour returned to opposition in June 1970. Removed from the shackles of office, anti-Community sentiment within the party began to grow almost instantly. A number of figures in the PLP for example claimed that not only was the new battleground in British politics the Common Market. It was, some felt, also an issue on which the Conservatives could reasonably be expected to split and from which Labour could gain much needed political capital ${ }^{29}$. Attitudes at the grass roots level also became more problematic. By the start of 1971 a steady stream of resolutions from constituency parties were reaching Transport House, many urging the Labour leadership to propose a referendum or a general election fought on the matter of British membership of the Community ${ }^{30}$. This was the beginning of the apparent >shift in both Labour's stance and that of Wilson's own position on European membership from predominantly supportive of British entry to increasingly sceptical ${ }^{31}$.

As for Wilson after 1970, outside of intra-party debates he still seemed as supportive of British membership as he had been before. In this regard, party-level meetings with his socialist counterparts were to prove important. Wilson himself suggested at the beginning of 1971 that there should be either a meeting of the Contact Committee or a leadership-level gathering to discuss Edward Heath's negotiations with Brussels ${ }^{32}$. This would not come about for some months, in the form of a gathering of leaders on the edge of the Socialist International in Helsinki. What is remarkable about Wilson's comments when the meeting did get underway was just how similar they were to statements he had made as prime

\footnotetext{
${ }^{29}$ LHA, NEC Minutes 22 July 1970, minutes of meeting of the NEC, 22 July 1970.

${ }^{30}$ LHA, NEC Minutes 27 January 1971, ID/1970-71/28, Resolutions received from Constituency Labour Parties and Trade Unions, January 1971.

${ }^{31}$ BROAD, Labour's European dilemmas (as in n. 8), p. 81; Ben PimLOTt, Harold Wilson, London 1992, p. 581-583.

32 LHA, NEC Minutes 27 January 1971, NEC 5/1970/71, comments by Wilson, 27 January 1971.
} 
minister. Thus, while he began by stating how officially there were several questions on which Labour »will decide its attitude« the overall impression he gave was positive, never straying further than to repeat as before that the party supported membership providing certain safeguards were met ${ }^{33}$. Irrespective of the domestic party debates that were already emerging over EC membership, then, comments made at an international level seemed to confirm that nothing had changed and that Wilson remained committed to securing British accession to the Community. This suggests that transnational party relations had a fifth function for the Labour party in addition to the four mentioned above. For the transnational setting could provide a measure of continuity for the leadership and a chance for them to discuss the intricacies of British membership at a time when domestic party politics caused opinions to vacillate and discussions over the basic premise of British accession to become ever more contentious.

For the likes of Labour's international secretary Tom McNally, cross-border party relations were now more salient than ever. Writing shortly after the Helsinki gathering, he explained: »There is a political value in the direct personal contact between party leaders $\aleph^{34}$. It is clear in such statements that transnational contact mattered to leading party figures at the time. As was to be the case following Labour's special conference, which was designed to debate the Conservatives' White Paper on EC membership published on 7 July 1971. Just ten days later, Wilson faced his most challenging test in party management since returning to opposition. Having stated at Helsinki that Labour was broadly supportive of membership, Wilson appeared to lurch decisively towards an anti-EC position ${ }^{35}$. This would end in the Labour NEC officially rejecting Heath's terms and demanding a referendum on continued British membership ${ }^{36}$. The consensus of the existing historiography is that party political calculations influenced Wilson's

\footnotetext{
${ }^{33}$ Bodleian, Harold Wilson papers, MS. Wilson c.1171, transcript of Wilson speech to Socialist International, 25 May 1971.

${ }^{34}$ LHA, NEC Minutes 23 June 1971, report on Socialist International conference in Helsinki 25-27 May 1971, 7 June 1971.

${ }^{35}$ Labour Party, Labour and the Common Market. Report of a special conference of the Labour Party, London 1971, p. 42-49.

${ }^{36}$ LHA, NEC Minutes 28 July 1971, minutes of meeting of the NEC, 28 July 1971.
} 
apparent change of heart ${ }^{37}$. In this analysis, Wilson sought to reinvigorate support for his leadership among the left wing in order to stave off a challenge from Jim Callaghan, then Labour's spokesman for the Home Office. Certainly Per Kleppe, present at the conference for the DNA and the party's trade and shipping minister, felt that Wilson's comments were party-related. »It was said to me«, he wrote in a later report, »that this was necessary for the cohesion in the party«. Callaghan, he continued, had positioned himself as a potential successor to Wilson and could use the trade unions to boost his support, but given that Wilson »had come off the fence and down on the critical side, he has averted this challenge from Callaghan. It was said to me that if Wilson had not done so, his position as party leader would have been seriously threatened $\aleph^{38}$.

Because of this perhaps, Wilson's supposed tilt against entry did appear to be a pragmatic decision made within an environment of party disunity and challenges to his leadership. The interesting thing from the perspective of this chapter is the subsequent efforts Wilson made to offset his remarks through partylevel cooperation. In fact, at a socialist leaders' meeting in Salzburg later in September 1971, and again the following year at the Socialist International conference in Vienna, Wilson consistently explained to his international colleagues that his position remained firmly that of supporting British membership of the Community. A report of the Salzburg meeting by the Danish SD even claimed that Wilson "assured the assembled socialist leaders that he and the Labour party were still basically very much in favour of progress towards the European unity« and that »a future Labour Government would not endeavour to take Britain out of the Common Market once she was in « ${ }^{39}$. Wilson's use of crossborder contact consequently suggests that such contact had an important role in sidestepping the domestic party arena, the Labour leader using transnational cooperation to inform other parties - and by virtue the governments of the Six

\footnotetext{
${ }^{37}$ Pimlott, Harold Wilson (as in n. 31), p. 582-583; Lynton RoBins, The Reluctant Party. Labour and the EEC 1961-75, Ormskirk 1979, p. 96-97.

${ }^{38}$ Arbeiderbevegelsens Arkiv og Bibliotek, Oslo, Per Kleppe papers, Da. Box 0044, Rapport fra det britiske arbeiderparti's ekstraordinære kongress 17 juli 1971, 4 September 1971.

${ }_{39}$ ABA, SDA, Box 1227, The International in Action, 9 June 1972. For Wilson's Vienna speech see LHA, Michael Foot papers, MF/C2, transcript of speech at Socialist International, 28 June 1972.
} 
themselves - his aims with regard to British membership. Wilson clearly sought to minimise any backlash from other leaders and used successive socialist conferences to indicate his true intentions. This would prove vital in earning goodwill for the renegotiations that the Labour leadership would subsequently undertake.

Threats to Labour's interests outside of Britain could also be dealt with by utilising links with its sister groups. The Labour leadership had always tried to conduct transnational relations in the context of an informal setting and beyond the media limelight. This remained effective for the most part, but other occasions required more interventionist, indeed more public signs of cooperation. The whole nature of party collaboration in particular changed in the run up to the Danish referendum on EC membership in October 1972. The SD leadership, engaged in a bitter dispute within its own ranks over Danish entry, arranged for a Labour figure to appear on Danish television to help make »direct, clear, simple, positive, sincere« statements, avoiding the »British way of politeness, modesty, understatements «. The figure would have to demonstrate not only that Britain intended to join and stay in the EC, but that a Labour Government »will not get England out«, that »England wants Denmark to join« and that »a Danish `no will not change the British position ${ }^{40}{ }^{0}$. As it transpired, George Brown was asked to fly to Denmark to support the SD and assist in the campaign for a >yes including backing Krag and the SD elite in their support for Danish entry. It was not hard to understand why Labour went to such lengths; Stewart remarked in his diary that a no vote in Denmark »will make the situation inside the Labour Party worse than ever « ${ }^{41}$. It was thus in the mutual interest of both party leaderships that Labour came to have a small but no less significant role in the Danish vote.

Just as Labour looked to be at its most divided domestically, then, so the leadership clearly engaged with its socialist counterparts to facilitate the first enlargement of the Community in 1973. In the same vein, leaders' meetings were a constant fixture in the years after the first enlargement, including in the period

\footnotetext{
${ }^{40}$ ABA, Jens Otto Krag papers, Box 120, note on British Labour guest, 29 September 1972.

${ }^{41}$ Churchil College Archives, Cambridge [henceforth CCA], Michael Stewart papers, STWT 8/1/7, diary entry 10 September 1972.
} 
that Labour once again assumed office and started to renegotiate British EC membership ${ }^{42}$. A first trawl of research seems to indicate that party contact perhaps played more of a role than might have been expected during the renegotiation process and in the resultant referendum. Central to this from Labour's viewpoint was its relationship with the German Social Democratic Party (Sozialdemokratische Partei Deutschlands, SPD), and in particular Helmut Schmidt. Notably, the German Chancellor addressed the Labour conference at the end of 1974 and he, Wilson and Callaghan were in constant contact over the content of Schmidt's conference speech. According to Callaghan's recollection of events, the SPD leader's comments made a positive impression on Labour delegates ${ }^{43}$. Moreover, in a meeting between Wilson and Schmidt at Chequers the following weekend the Labour leader seems to have finally committed to Britain retaining its membership of the $\mathrm{EC}^{44}$. Even prior to the Dublin Summit of March 1975 - during which final aspects of the renegotiated terms were due to be settled - it thus seems Schmidt had helped convince the prime minister of Britain's fate, his concerns over the terms of continued membership allayed by concessions made during his meeting between the two men. But Schmidt's presence at the Labour conference seemed more significant. In a sense, they helped prevent the party rejecting the ongoing negotiations there and then. Instead, the conference simply backed a motion that called for the referendum to have »top priority « for the government and for there to be a »balanced presentation of the views of those for or against membership « ${ }^{45}$. Little wonder, then, that when later reflecting on the British renegotiations Schmidt would describe it as nothing more than a cosmetic operation necessary to keep Labour divided on the question ${ }^{46}$. For renegotiation was essentially a party issue and Schmidt had played no small part

\footnotetext{
${ }^{42}$ For instance LHA, NEC Minutes 26 June 1974, minutes of international sub-committee, 11 June 1974.

${ }^{43}$ James CAllaghan, Time and Change, London 1988, p. 311-312. See also BROAD, Labour's European dilemmas (as in n. 8), p. 102-103.

${ }^{44}$ Hugh YOUNG, This Blessed Plot. Britain and Europe from Churchill to Blair, London 1998, p. 283. See also Julie Sмітн, The 1975 Referendum, in: Journal of European Integration History 5 (1999), p. 47.

${ }^{45}$ Labour Party, Labour Party Annual Report London 1974, p. 249.

${ }^{46}$ Young, The Blessed Plot (as in n. 44), p. 282-283.
} 
in prolonging what seemed an inevitable split for just that little bit longer. His speech, even for prominent Eurosceptic Barbara Castle, was »masterly « ${ }^{47}$.

All of this does seem to indicate that the historian trying to contend with Labour's European policy in the 1970s needs to be mindful of party policymaking beyond the national setting. There is no doubt, as is well known, that the Labour party became increasingly factious after 1970. On the contrary, Labour's leaders were engaged with their socialist counterparts in Europe and presented an entirely different message at the transnational level than to the one proffered at the domestic one. Wilson had clearly accepted the need for Britain to join and this remained a constant policy goal even after Labour moved back into opposition in 1970. In this sense, transnational relations proved a useful avenue to achieve the leadership's goals at a time when party infighting effectively excluded the opportunity for Wilson and his team to champion British membership so forthrightly at home.

\section{Cementing a place in the Community}

After the referendum in June 1975 there was a gradual shift in emphasis from the Labour elite with regard to cross-border party relations. No longer did it use contact exclusively to facilitate British membership, rather in shaping the policies adopted by the Community of which Britain was now a member. In such a way, transnational cooperation appeared to develop a far more significant agendasetting function after Britain's place in the Community was secure following the positive referendum result. The job of governing, in other words, could now get underway.

Within a transnational socialist setting, the question of Portugal took priority. In the words of Wilson, following the aftermath of the Carnation Revolution »not only Britain, but all our [EC] colleagues, were committed to support a democratic solution there«, a task made no easier by the apparent rise in influence of Portuguese communists ${ }^{48}$. Against this backdrop, there were calls

\footnotetext{
${ }^{47}$ Barbara CASTLE, The Castle Diaries 1974-76, London 1980, entry for 29 November 1974, p. 241.

${ }^{48}$ Wilson, Final Term (as in n. 6), p. 168.
} 
from Olof Palme of the Swedish Socialist Party (Sveriges socialdemokratiska arbetareparti) to hold in August 1975 a socialist leaders' meeting to give support to Portuguese socialists, something agreed to by Wilson. This was important. During the course of the referendum campaign the NEC had declined to assist those socialists who sought to coordinate the policies of Community states towards Portugal ${ }^{49}$. Within less than two months of the referendum however, the Labour leader now saw fit to engage with socialist colleagues on the question. Wilson, together with Palme, Bruno Kreisky, Willy Brandt (still SPD chair though no longer chancellor) and the Dutch socialist leader and then premier Joop den Uyl agreed to give Mário Soares »all possible help« with »the problem of strengthening democracy in Portugal«. Not only did the men recognise the need to give financial subsidies to the Portuguese channelled through the EC, but they also established the Committee of Friendship and Solidarity with Democracy and Socialism in Portugal to provide a permanent link between socialist parties, EC governments and Soares' party in Portugal ${ }^{50}$. In other words, the transnational socialist framework was increasingly useful for developing policies that EC governments more generally might later pursue.

Significantly, sections of the Labour party increasingly refused to accept the referendum result. After a brief period of solidarity in Labour's ranks, the likes of Castle soon questioned whether the party should accept future Community policies $^{51}$. Such a refrain became more common, some doubting whether a >yes vote in the referendum translated into support for direct elections or EMU ${ }^{52}$. This makes the activity of the Labour leadership at the transnational level all the more remarkable. For despite the ongoing debates within Labour over the merits of British membership, the party leadership showed itself to be an active partner in Community policy-making at the European level. More important still, the environment of such action seemed to coalesce in the framework of transnational socialist party links. Following on from Wilson's discussions over Portugal, his

\footnotetext{
${ }^{49}$ LHA, NEC Minutes 21 May 1975, minutes of international sub-committee, 6 May 1975.

${ }^{50}$ WiLSON, Final Term (as in n. 6), p. 175-182.

${ }^{51}$ CASTLE, The Castle Diaries (as in n. 47), p. 650, entry for 5 June 1975.

${ }^{52}$ BROAD, Labour's European dilemmas (as in n. 8), p. 124-132.
} 
successor, Jim Callaghan, continued to maintain close relations with key European socialist figures like François Mitterrand and Schmidt. Monetary aid was on the agenda when Callaghan and Brandt, by now president of the Socialist International, discussed the Community financing development programmes in southern Europe ${ }^{53}$. Similarly, Callaghan's foreign secretary, David Owen, agreed to work with French socialists, then out of office, to try to combat the growth of communist parties in Community states. As Owen himself remarked, »There was a tendency to forget politics in inter-governmental contacts but [...] socialist parties in Government must help their socialist friends, within the Community « ${ }^{54}$. With Owen's comments in mind, transnational links no doubt had a role to play between Community states and third countries, including as an avenue for retaining contact between the EC and Norway ${ }^{55}$.

Old habits die hard however, and few of these actions could hide the fact that the Labour party more generally after 1975 seemed only to grow more hostile to EC policy-making in much the same way as the party leadership warmed to its newfound role as a Community actor. Notwithstanding Labour's membership of the Socialist International, one area that remained especially contentious was the party's involvement in institutionalised groupings at the European level, namely the EP Socialist Group and the Confederation of the Socialist Parties of the $\mathrm{EC}^{56}$. Both were important institutions in their own right with links to the Socialist International. Previous authors are to an extent correct to pronounce Labour's reservations over party cooperation at the European level ${ }^{57}$. For the PLP, NEC and party rank-and-file doubtless all met both the Socialist Group and Confederation with near-universal suspicion. Some - most obviously Peter Shore but also a considerable number of backbenchers in the PLP - even debated whether

\footnotetext{
${ }^{53}$ Bodleian, Uncatalogued papers of Lord Callaghan 1977, note of meeting between Callaghan and Brandt, 30 March 1977.

${ }^{54}$ Bodleian, Uncatalogued papers of Lord Callaghan 1978, minutes of meeting between Owen and Pierre Mauroy, 13 January 1978.

${ }^{55}$ Bodleian, Uncatalogued papers of Lord Callaghan 1977, note of socialist leaders' meeting in Oslo, 30 March 1977.

${ }^{56}$ On the Socialist Group and the Confederation see among others Simon HIX and Urs LESSE, Shaping a vision. A history of the Party of European Socialists 1957-2002, Brussels 2002.

${ }^{57}$ For instance: HIX and LORD, A model transnational party? (as in n. 7), p. 89: HAAHR, Looking to Europe (as in n. 7), p. 80-81.
} 
Labour's prospective eighteen members should join the Socialist Group at all now the party had decided to take up its seats in the EP, fearing as they did the apparently federalist aspirations and right-wing ideologies of the other socialist groups $^{58}$. Linked to such inactivity, the party likewise continued to resist joining the Confederation after the referendum. When it did finally agree to work with it in April 1976, yet again it did so reluctantly and even then only as an observer ${ }^{59}$.

This was symptomatic of the party's hostile attitude to direct elections in the years that preceded the 1979 vote. Not all of the Labour movement was against them of course; some saw direct elections as a logical expansion of democratic control over the Community's institutions. Yet the most explicit fear for sceptical Labour figures, and the one that dominated the NEC and much of the PLP prior to 1979, was that direct elections were emblematic of a more general shift toward some sort of federal system ${ }^{60}$. Trepidation over direct elections fed into existing discontent over EMU, Brussels' control over tax policy and the concept of free movement of capital, all of which were given as examples of Community overreach. At the same time, the NEC sought reform to an array of existing policies, not least the Community's agricultural and overseas aid policies. On direct elections specifically, the likes of Jennie Lie expressed concern over 'different electoral traditions', a nod to the fact that some thought an EC-wide vote would mean all nine Community countries having to adopt the same electoral system both in future EP and national plebiscites. Questions surrounding the date of direct elections and the issue of dual mandates - whether MPs in the Commons could also split their time by representing a European constituency - provoked similar controversy. And the weaknesses of the European Parliament were likewise deployed for the sceptics' ends: »How could elections be justified to a body which had no powers? « the NEC heard in March $1976^{61}$. The next year saw

\footnotetext{
${ }^{58}$ BROAD, Labour's European dilemmas (as in n. 8), p. 124-125.

${ }^{59}$ LHA, NEC Minutes 26 November 1975, minutes of international sub-committee, 11 November 1975.

${ }^{60}$ LHA, NEC Minutes 25 February 1976, ID/1975-76/69, Report of meeting of bureau of Confederation of the Socialist Parties of the European Community, 18 January 1976.

${ }^{61}$ LHA, NEC Minutes 25 February 1976, ID/1975-76/69, Report of meeting of bureau of Confederation of the Socialist Parties of the European Community, 18 January 1976.
} 
conference vote by a two to one margin against British involvement in direct elections $^{62}$. The NEC only changed its mind later on when it was clear that the vote would take place regardless of Labour's position.

Naturally, the intensity of all of these views did not stop the leadership from adopting a different approach. In fact, within seven days of the referendum the Labour leadership maintained its support for direct elections - regardless of the views of the PLP, NEC or wider movement ${ }^{63}$. This was some eight months before the government published a White Paper detailing its policy on them. Subsequent assurances given by Callaghan throughout the next three years - that the government would only adopt a policy on direct elections in line with the party were therefore little more than a window-dressing exercise to appease party Eurosceptics $^{64}$. The leadership's stance towards direct elections mirrored its approach to formalised relations with other socialist groups within the framework of the Community. With regard to the EP Socialist Group, Labour officials were adamant that the party's representatives - officially called the Labour Group should join the larger Socialist Group of parties in the EP immediately after the referendum, again despite the doubts expressed by certain sections of the NEC and PLP. Not joining, as Roy Hattersley noted, would »be seen as a tremendous affront by our sister parties in the Socialist International ${ }^{65}$. According to McNally, becoming members of the Socialist Group might also help in »nursing the Labour Group into a constructive posture within the European Parliament ${ }^{66}$.

For all the party's hesitancy over the Socialist Group, therefore, the leadership maintained from the moment of the referendum that Labour had to be a full and active member of the EP alongside its socialist counterparts. As part of this goal, McNally and Cledwyn Jones, the pro-European PLP chair, turned to the German head of the EP Socialist Group, Ludwig Fellermaier. Between them, the three men discussed possible leaders of the Labour contingent who could best ensure that the party cooperated fully with other socialist parties in the EP; only a

\footnotetext{
${ }^{62}$ HAAHR, Looking to Europe (as in n. 7), p. 79.

${ }^{63}$ Bodleian, Uncatalogued papers of Lord Callaghan 1975, Hattersley to Callaghan, 13 June 1975.

${ }^{64}$ Bodleian, Uncatalogued papers of Lord Callaghan 1977, Lipsey to McNally, 3 March 1977.

${ }^{65}$ Bodleian, Uncatalogued papers of Lord Callaghan 1975, Hattersley to Mellish, 4 June 1975.

${ }^{66}$ Bodleian, Uncatalogued papers of Lord Callaghan 1975, McNally to Callaghan, 7 July 1975.
} 
"person with experience and sensitivity of what has been happening in the Party over the last few years « would do, the three men agreed ${ }^{67}$. What was more, they carved out a plan for Labour to occupy the vice-president position within the Socialist Group. This, they hoped, would bind the party's members as closely as possible into the EP grouping. Furthermore, as part of its activities Fellermaier agreed to give Labour members greater say in specific working groups of the Socialist Group at the request of McNally and Hughes. Involvement in regional and industrial working parties of the Socialist Group were uncontentious issues, so McNally and Hughes hoped, and would provide a convenient distraction from the question of direct elections that otherwise dominated the thoughts of those who were likely to represent the party in the EP prior to the 1979 direct elections $^{68}$. By the mid-1970s, the Labour leadership were thus adept to use informal, coordinated meetings with socialist figures in Europe to qualify the continued Euroscepticism that Labour continued to exhibit domestically. In effect, the Labour leadership seemed to hope that a degree of socialisation would take place on its own cohort of representatives as they engaged in the work of the Socialist Group.

The informal political channels developed by the leadership described above could not help but have an impact on subsequent party policy towards European issues. They likely eased the NEC's position on fighting the direct elections on a joint platform with the Confederation. For although the NEC excluded the idea, large elements of Labour's manifesto for the elections was drawn from the Confederation's document with only those elements on federalism deleted from the final version. ${ }^{69}$ And the joint home and international committee of the NEC even accepted the need to engage fully with the Confederation prior to the elections, as well as other national parties, even though there was a clear

\footnotetext{
${ }^{67}$ Michael Stewart occupied the position until December 1976, at which point Labour's delegation chose John Prescott - not known for this European sympathies - as his successor, see Anita POLLACK, Wreckers or Builders? A History of Labour MEPs 1979-1999, London 2009, p. 2.

${ }^{68}$ Bodleian, Uncatalogued papers of Lord Callaghan 1975, Roper to Hughes, 24 June 1975 and McNally to Callaghan, 26 June 1975.

${ }^{69}$ Bodleian, Uncatalogued papers of Lord Callaghan 1979, report of consultation with candidates and election agents for European Assembly, 11-12 May 1979.
} 
differentiation between its views and those of other socialist groups ${ }^{70}$. As a result, membership of the Socialist Group and the Confederation became relatively normalised; the party's representatives in the EP were remarkably active and, despite clear policy differences, they worked well with their counterparts in the European Parliament and officials in the Confederation ${ }^{71}$. It is thus reasonable to identify the groundwork put in by the leadership as one factor why despite the numerous doubts about Labour's institutional links in the Community that were still rabid in the party, it did in fact engage with its counterparts at the European level. Once again, contact with socialist parties at the transnational level and within the Community structure do indicate that the popular narrative of Labour in the 1970s ought to be at least modified to reflect these elements.

\section{Conclusions}

Looking back on Labour's recent past, the 1970s stand out as a desperate and depressing decade for the party. Not only did it witness tribal warfare like never before on the question of European membership. Labour also had to contend with Britain's relative economic decline in the aftermath of the 1973 oil crisis and continued problems connected to increased labour turmoil and trade union strikes. Over time of course this would go some way to explaining the electoral decline of the party after 1979, a trend that would continue until its resurgence as New Labour and subsequent electoral victories under the leadership of Tony Blair. What, then, by re-examining Labour's European policies in the 1970s can we add to this more typical picture of malaise and disunity? For a start, like the late 1950s and 1960s, the 1970s saw a huge amount of engagement by the Labour leadership with its socialist counterparts. The Labour elite clearly sought out, and saw value in, contact with other socialist groups in Western Europe. By focusing on such relations, it is equally clear that the years leading to direct elections in 1979 saw a good deal more consistency in the approach adopted by the Labour leadership to European integration than is often considered the case. In short, once the party

\footnotetext{
${ }^{70}$ Bodleian, Uncatalogued papers of Lord Callaghan 1979, minutes of NEC European liaison committee, 7 March 1979.

${ }^{71}$ POLLACK, Wreckers or Builders? (as in n. 67), p. 1-4.
} 
elite had committed to EC membership around 1966 they remained so thereafter and socialist party cooperation was to provide a mechanism to help achieve this aim. Furthermore, once Britain's place in the Community had been secured by virtue of the 1975 referendum, the 1970s also saw socialist links become a vehicle through which the Labour elite could hope to shape EC policies more generally. As part of this, the party leadership exhibited a remarkable degree of support for the Confederation and EP Socialist Group.

That as a result of such actions Labour actually fought in the direct elections in 1979 is, however, perhaps the most significant point to take from this chapter. In one respect it was an important moral and political victory for the leadership at a time when its authority was being increasingly challenged. More notable still, it also ensured that Labour remained a part of the Community apparatus even when domestically the party campaigned for British withdrawal under the leadership of Michael Foot. But it is perhaps in the medium- to long-term that the real significance of the decision to work with the Socialist Group, to associate with the Confederation and to take part in the direct elections becomes most obvious. For Labour representatives would after 1979 cement their position in the EP and find the value of the organisation as a platform to attack the policies of Margaret Thatcher. They would become involved in sponsoring resolutions and would work in an ever-growing number of parliamentary committees. And by the early 1990s Labour members would take a front seat in the legislative process and within the newfound Party of European Socialists, utilising the increasing powers of the parliament to formulate responses to a whole host of international issues in the shape of German reunification, the Gulf War and the Treaty of Maastricht ${ }^{72}$. In this sense, the efforts made by the Labour leadership in the mid- to late-1970s helped shape profoundly the work, policies and influence of the EP itself and ultimately the position of the parliament as an actor in the more general infrastructure of the Community and later European Union.

Taken together, these points do therefore suggest that it is vital to fit socialist party cooperation beyond the national level into the more general

${ }^{72}$ On these developments see POLLACK, Wreckers or Builders? (as in n. 67), p. 113-216. 
narrative of Labour's European policy in the 1970s. In so doing, a slightly more nuanced story of the party in this period becomes apparent, one where the leadership was, despite the travails that beset the party in this period, not as awkward a partner as is often claimed. The relationships certain party figures developed with their socialist counterparts before 1979 go some way to proving as much. 